\title{
Peer Teaching Intervention to Enhance Applied Mathematics Performance of Technology Student in Mizan-Tepi University
}

Tesfaledet Tsegay Mena*

Assitance Professor, Msc in Biostatistics, Department of Statistics, Wolkite University, Ethiopia

DOI: $10.36347 /$ sipms.2020.v07i03.001

| Received: 17.03.2020 | Accepted: 25.03.2020 | Published: 30.03 .2020

*Corresponding author: Tesfaledet Tsegay Mena

Abstract

Original Research Article

Mathematics is considered the mother of all learnings in both Arts and Sciences. It is a tool for understanding structures, relationships and patterns to produce solutions for complex real-life problems. But many students possessed of negative perception on mathematics as an academic discipline. This study aimed to investigate the effects of peer learning strategy in enhancing the performance level of technology students in Applied Mathematics at Mizan-Tepi University, Tepi. This study was conducted in two different steps the first one deal with collection of raw data from registrar and alumni management to select low achiever student in first semester particularly in applied Mathematics course for baseline information. The study was conducted over eight-week periods in the second semester of 2019/20 academic year, in 46 (29 males, 17 females) first year engineering students, College of Engineering and Technology, Mizan-Tepi University, Ethiopia. Indeed, the study involved two groups; experimental (24) students and control group (24) students. The result shows that there is a significant difference between the experimental group and control group in mathematics academic achievement in the post- result. The result means that the null hypothesis is rejected and accepting the alternative hypothesis, which states that: There is a significant statistical difference at $(\alpha=0.01)$ in mathematics academic achievement of the technology students in Mizan-Tepi university attributed to the peer teaching strategy. The results suggest that peer teaching strategy has a positive effect on the academic achievement of mathematics.

Keywords: Science Club, Peer Teaching, Mizan-Tepi.

Copyright @ 2020: This is an open-access article distributed under the terms of the Creative Commons Attribution license which permits unrestricted use, distribution, and reproduction in any medium for non-commercial use (NonCommercial, or CC-BY-NC) provided the original author and source are credited.

\section{INTRODUCTION}

Mathematics is considered the mother of all learnings in both Arts and Sciences. It is a tool for understanding structures, relationships and patterns to produce solutions for complex real-life problems. But many students possessed of negative perception on mathematics as an academic discipline. This feeling effectively hindered their potential to learn and understand mathematical problem. Consequently, for them to cope with the negative perception, modern day teachers and scholars employed innovations in teaching mathematics to help students overcome fears and improve their performance on the subject. While providing appropriate method to study mathematics is found to be relative, debates on the issue remain the subject of many scholarly studies. It is believed that cooperative learning can considerably improve students' level of performance in the subject compared to the conventional/traditional method of teaching [1].
Mathematics is also important in our daily life. It is the tool and language of almost all fields of science. It helps us recognize patterns and understand the world around us. Many students in elementary, high school and even at the university level find that mathematics is difficult and challenge because it is an abstract discipline. Therefore, mathematics instructors try to create a math-friendly environment to help their students meet this challenge. One way to achieve this is by giving students an opportunity to learn and study collaboratively. For example, students can work together in groups.

A scholar suggested that in order for learning to take place, people should talk and interact with each other. People naturally learn from each other and work cooperatively in their everyday lives. Moreover, cooperative and peer learning approach as important part of a process which leads to the social construction of knowledge [2]. 
Different research result shows that peer interaction can have a great impact on academic achievement and motivation as well [3, 4]. Similarly, it has been showed that the socialization process which takes place during the peer teaching is useful and helpful for both, tutor and tutee. It increases the motivation of the students to learn and in the same time the social standing among peers will be much better [57].

Peer teaching is a subset of cooperative learning. Further it can be defined as teaching system in which learners cooperate with each other [8]. One of them (peer teacher) conveys knowledge and skills that he has mastered to other students (peer learner) under the supervision of the teacher. reported that peer teaching is an interactive approach including two students. One of them takes the role of the teacher and the other takes the role of the learner. Peer teaching considered as a mutual learning process in which students teach others the desired skills and knowledge with full coordination with their teacher in case there are any comments or questions. However, the teacher should be around always to solve immediately any problems may arise between students $[9,10]$.

Researches show that peer teaching is useful and has many benefits for students and teachers. A reported that peer teaching is helpful for fast learners and slow learners as well. It helps fast learners to master the concepts related to the course and confidently express their ideas. Slow learners improve and develop their performance and get a better understanding of the terms of the lessons. Peer teaching helps both, fast learners and slow learners in developing important values such as sharing, self-esteem, and selfdiscipline. Other study reported that students working in groups perform better on exams especially questions that involve reasoning and critical thinking skills. Actually; peer teaching, a type of collaborative learning, often happens spontaneously with a group of students. In fact, educators have found through experience and their research that peer teaching is an effective strategy in helping learners achieve the educational goals $[11,12]$.

Although the name 'peer teaching' sounds straight forward, it is in fact a complex process by which a student learns from another student who has more experience and knowledge. It also considered peer teaching as communication between an excellent student, who is doing very well or who recently completed the course successfully, and another student encountering difficulty in the same course. In line that peer teaching is one of the most effective strategies in the teaching and learning process because it deals with the social as well as the academic side of learning by creating a comfortable environment for teaching and $[13,14]$

\section{OBJECTIVE OF THE STUDY}

This study aimed to investigate the effects of peer learning strategy in enhancing the performance level of technology students in Applied Mathematics at Mizan-Tepi University, Tepi. Specifically, the study sought to:

a. Describe the performance level of the students on the control and experimental group before and after the experiment.

b. Assess the effectiveness of Peer learning.

c. Determine the impact of Peer learning on students' performance in Applied Mathematics.

The generalization of the findings of this study will be limited by:

1. A sample of undergraduate students admitted in Mizan-Tepi University on 2019/20 academic year, College of Engineering and Technology.

2. Applied Mathematics courses

3. Using Student peer teaching method undergo by since club that has been recognized under college of natural and computational science.

4. The validity and reliability of the tools used to collect data.

\section{MATERIAL AND METHODS}

This study was conducted in two different steps the first one deal with collection of raw data from registrar and alumni management to select low achiever student in first semester particularly in applied Mathematics course for baseline information. The second phase will be making an intervention on selected student by peer learning method using science club that has been introduced under college of natural and computational science.

Since club is one of association in Mizan-Tepi University that has been recognized under College of Natural and Computational Science academic commission set as an objective helping students within and among colleges by graduate students for first year students especially for those comes from hard science departments (Mathematics, Statistics and Physics).

\section{The Study Sample}

The participants of the study are students enrolled in the course "Applied Mathematics II". To ensure that there is no effect of the instructor on the results of the study, all participants should be taught by the same instructor. To maximize the number of participants, we selected the instructor who had the largest number of sections.

\section{Study Design and Variables}

This study used the Pretest-Posttest Controlexperimental group design using two groups of MizanTepi University, first year college of Engineering and Technology students. The first group taught with peer 
teaching strategy while the other group taught without peer teaching.

The quasi-experimental design was chosen because it was not possible to randomly assign students to either the treatment or the control group as the group (classroom) was already formed [15]

The result of first semester showed that the presence of failure of student considered less than $50 \%$ for total assessment out of $100 \%$.

In this study peer teaching method was considered as independent variable similarly the respective student academic achievement in applied mathematics course was considered as dependent variable.

\section{Procedure}

The study was conducted over eight-week periods in the second semester of 2019/20 academic year, in 46 (29 males, 17 females) first year engineering students, College of Engineering and Technology, Mizan-Tepi University, Ethiopia. Indeed, the study involved two groups; experimental (24) students and control group (24) students.

The criteria for the selection was teaching at least three sections as they serve as the control and experimental groups. Dr. P. Shanmuga Sundaram was the best choice because he had three sections from two department (Civil and Hydraulics Engineering) with an average of 48 students in each section. The total number was around 145 students.

The result of the first semester showed that the percent of the failures of Dr. P. Shanmuga's students was around $43 \%$ or 62 students. The students were classified in to experimental group they have been attained full peer tutorial program conducted by the science club hence we got only 23 students. Similar number of students randomly selected as control group they will never attain the tutorial program.

Generally, the following major action was taken as an intervention

- Organizing Peer teaching (student as a teacher) members based on their interest and previous academic achievement

- Organizing Appropriate peer teaching time

- Providing Available materials

- Carry out continuous supervision

- Organizing Appropriate class rooms, light, for study group

- Incentives, praises for students participated Peer teaching (student as a teacher)

We created a motivation for the peer teaching by providing a one-hour discussion for the challenges and opportunities of the Peer-teaching.

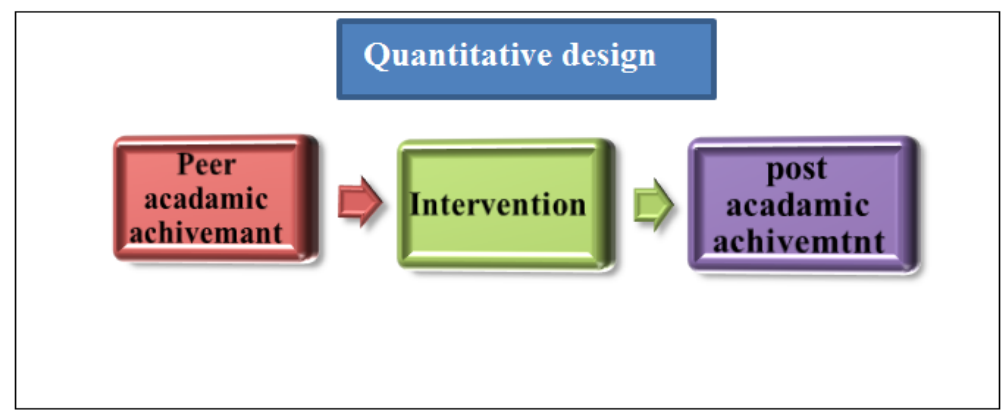

\section{Operational Definitions}

Two main terms involved in the study: Peer Teaching and Student Academic Achievement.

Peer Teaching: A strategy by which student teaches other students that are weak and less experienced about a certain subject. Peer teaching can be applied in different approaches. Abu Shaban identified different types of peer teaching [16]:

- Discussion groups: small groups guided by student teaching assistant. The groups are used to supplement large lectures. The student teaching assistant is selected among students who previously have done well in the course.

- One-to-one tutoring: One skillful student (peer teacher) and one student (peer learner) who is weak or less skillful.
- Student Learning Groups-In which students learn and work in self-guided groups to enhance peer learning.

The researchers followed the first approach in this study (Discussion groups). There was a student teaching assistant who comes from graduate class of mathematic department previously studied the course and well done. This student attended the classes of the experimental group. He/she was close to the students and whenever the instructor started the guided practice phase, He/she was following up the students, explaining, giving hints, and even teaching whenever it is necessary.

Student Academic Achievement: It was measured by student score in Applied Mathematics I and II examination that was prepared by the Instructor. 
Data Analysis

To describe the student's performance level before and after the experiment of peer teaching, the frequency count and the level of different actors was assessed.

To assess the effectiveness of peer learning method on the performance level of students in Applied Mathematics, the t-test for paired and independent variable was used for the comparison of post-test of two samples. To determine the impact of cooperative learning method on the students' performance the t-test for dependent variable was applied on experimental group.

\section{RESULTS AND DISCUSSION \\ Statistical Data Analysis}

The analysis is carried out in two sections. In the first section, results of descriptive statistics are presented; in the second section, we examined the effect of peer teaching on student mathematics achievement using paired t test with the help IBM SPSS statistics 20 .

\section{Result of descriptive statistics}

The basic background information of student under the project presented below in Table-1 show that $60.9 \%$ of the student was come from civil engineering department similarly $39.1 \%$ (18) of the student was from Hydraulics Engineering department. Table-1 also show that Out of 46 students $52.2 \%$ (24) and $47.2 \%$ (22) were male and female, respectively.

Table-1: Frequency of Department and Sex of the student

\begin{tabular}{|l|l|l|l|}
\hline \multirow{2}{*}{ Department } & Category & Frequency & Percent \\
\cline { 2 - 4 } & Civil Engineering & 28 & 60.9 \\
\cline { 2 - 4 } & Hydraulics Engineering & 18 & 39.1 \\
\hline \multirow{2}{*}{ Sex } & Male & 24 & 52.2 \\
\cline { 2 - 4 } & Female & 22 & 47.8 \\
\hline
\end{tabular}

\section{Peer teaching result}

Table-1 show that the mean and standard deviation of the student score in applied mathematics I out of $100 \%$ (pre-test). Referring to Table-1 presented.
The mean score of the control group is (44.91), while that of the experimental group is (43.96). Similarly, a minimum possible score was 40 and 41 for control and experimental group respectively.

Table-2: Descriptive statistics of students Pre-Mathematics achievement

\begin{tabular}{|l|l|l|l|l|l|}
\hline & Group & N & Min (Max) & Mean & Sd. Deviation \\
\hline Pre-Mathematics achievement & Control & 23 & $40(49)$ & 44.91 & 2.372 \\
\cline { 2 - 7 } & Experimental & 23 & $41(49)$ & 43.96 & 2.477 \\
\cline { 2 - 6 } & Over all & 46 & $40(49)$ & 44.43 & 2.446 \\
\hline
\end{tabular}

Table $2 \& 3$ below show that the mean and standard deviation of the student score in applied mathematics I out of $100 \%$ (pre-test) presented. According to Table-1 the mean score of the control group is (42.61), while that of the experimental group is (52.04). Similarly, the maximum possible score was 62 and 68 for control and experimental group respectively.

Table-3: Descriptive statistics of students Pre-Mathematics achievement

\begin{tabular}{|l|l|l|l|l|l|}
\hline & Group & N & Min (Max) & Mean & Sd. Deviation \\
\hline Post-Mathematics achievement & Control & 23 & $30(62)$ & 42.61 & 6.576 \\
\cline { 2 - 6 } & Experimental & 23 & $39(68)$ & 52.04 & 7.900 \\
\cline { 2 - 6 } & Over all & 46 & $30(68)$ & 47.33 & 8.626 \\
\hline
\end{tabular}

To check if the difference in the means of the post- test is statistically significant or not, an analysis of t-test has been done. The hypothesis was

Ho: there is no significant difference between pre and post result of achievement in control group

$\mathrm{H} 1$ : there is significant difference between pre and post result of student in control group

The result presented in Table- 4 below shows that "there is a significant difference in the means of the experimental group (Mean=43.96, Standard deviation=2.477) and the control group (Mean $=44.91$, Standard deviation $=2.372$ ) of the Pre- result; $\mathrm{t}(\mathrm{df}=44)=$ $1.338, \mathrm{p}=0.715 \%$. Hence the test was insignificant rejecting the null hypothesis. Based on this analysis the two groups (The experimental group and control group) are considered equivalent before any action (peer teaching) employed. 
Tesfaledet Tsegay Mena., Sch J Phys Math Stat, March 2020; 7(3): 34-39

Table-4: T-test Result Comparing Experimental and Control Groups on Mathematics Achievement Before Treatment

\begin{tabular}{|c|c|c|c|c|c|c|c|c|c|c|}
\hline \multicolumn{11}{|c|}{ Independent Samples Test } \\
\hline \multicolumn{4}{|c|}{ Levene's Test for Equality of Variances } & \multicolumn{7}{|c|}{ t-test for Equality of Means } \\
\hline & & \multirow[t]{2}{*}{$\mathrm{F}$} & \multirow[t]{2}{*}{ Sig. } & \multirow[t]{2}{*}{$\mathrm{t}$} & \multirow[t]{2}{*}{ df } & \multirow[t]{2}{*}{$\begin{array}{l}\text { Sig. (2- } \\
\text { tailed) }\end{array}$} & \multirow[t]{2}{*}{$\begin{array}{l}\text { Mean } \\
\text { Difference }\end{array}$} & \multirow[t]{2}{*}{$\begin{array}{l}\text { Std. Error } \\
\text { Difference }\end{array}$} & \multicolumn{2}{|c|}{$\begin{array}{l}5 \% \text { Confidence Interval } \\
\text { of the Difference }\end{array}$} \\
\hline & & & & & & & & & Lower & Upper \\
\hline \multirow[t]{2}{*}{$\begin{array}{l}\text { Pre } \\
\text { result }\end{array}$} & $\begin{array}{l}\text { Equal } \\
\text { variances } \\
\text { assumed } \\
\end{array}$ & .092 & 763 & .338 & 44 & .188 & .957 & .715 & -.485 & 2.398 \\
\hline & $\begin{array}{l}\text { Equal } \\
\text { variances not } \\
\text { assumed }\end{array}$ & & & .338 & 43.919 & .188 & .957 & .715 & -.485 & 2.398 \\
\hline
\end{tabular}

*significant at $5 \%$

To check if the difference in the means of the post- test is statistically significant or not, an analysis of t-test has been associated. Table 4 explains the results.

Table-5 shows that "there is a significant difference in the means of the experimental group $(\mathrm{M}=52.04, \mathrm{SD}=7.9)$ and the control group $(\mathrm{M}=42.61$, $\mathrm{SD}=6.576)$ of the post- test; $\mathrm{t}(44)=2.143, \mathrm{p}=0.00$ ". Table-4 shows that there is a significant difference between the experimental group and control group in mathematics academic achievement in the post- result. The result means that the null hypothesis is rejected and accepting the alternative hypothesis, which states that: There is a significant statistical difference at $(\alpha=0.01)$ in mathematics academic achievement of the technology students in Mizan-Tepi university attributed to the peer teaching strategy. The results suggest that peer teaching strategy has a positive effect on the academic achievement of mathematics.

Table-5: T-test Result Comparing Experimental and Control Groups on Mathematics Achievement Before Treatment

\begin{tabular}{|c|c|c|c|c|c|c|c|c|c|c|}
\hline \multicolumn{11}{|c|}{ Independent Samples Test } \\
\hline \multicolumn{4}{|c|}{ Levene's Test for Equality of Variances } & \multicolumn{7}{|c|}{ t-test for Equality of Means } \\
\hline & & \multirow[t]{2}{*}{$\mathrm{F}$} & \multirow[t]{2}{*}{ Sig. } & \multirow[t]{2}{*}{$\mathrm{t}$} & \multirow[t]{2}{*}{$\mathrm{df}$} & \multirow[t]{2}{*}{$\begin{array}{l}\text { Sig. (2- } \\
\text { tailed) }\end{array}$} & \multirow[t]{2}{*}{$\begin{array}{l}\text { Mean } \\
\text { Difference }\end{array}$} & \multirow[t]{2}{*}{$\begin{array}{l}\text { Std. Error } \\
\text { Difference }\end{array}$} & \multicolumn{2}{|c|}{$\begin{array}{l}5 \% \text { Confidence Interval } \\
\text { of the Difference }\end{array}$} \\
\hline & & & & & & & & & Lower & Upper \\
\hline \multirow{2}{*}{$\begin{array}{l}\text { Post } \\
\text { result of } \\
\text { control } \\
\text { group }\end{array}$} & $\begin{array}{l}\text { Equal } \\
\text { variances } \\
\text { assumed }\end{array}$ & .782 & .189 & -4.402 & 44 & .000 & -9.435 & 2.143 & -13.754 & -5.115 \\
\hline & $\begin{array}{l}\text { Equal } \\
\text { variances } \\
\text { not assumed }\end{array}$ & & & -4.402 & 42.599 & .000 & -9.435 & 2.143 & -13.758 & -5.111 \\
\hline
\end{tabular}

\section{Implication and Multiplier Effects}

Students may feel more at ease when they deal with a peer tutor rather than their teacher or advisor, which enable them to study better and concentrate more on the subject matter allowing for better understanding of the concepts [17].

Also, students spend more time in the learning process and there is a direct interaction in which the student is open and feels comfortable which foster the active learning. Actually, peer teaching improves the cognitive gain and social gain as well [18].

The current study shows that peer teaching is an active tool in improving the performance of the students in applied mathematics at the university level. In the light of the findings, the study recommended the instructors and academic advisors to use peer teaching as a very good strategy to help students in increasing their achievement.
It has been indicated in the project peer teaching has a significance effect on student academic achievement of selected sample student so to make this project institutionalized the following key points should be considered.

- Science club should be supported by different resources including financial issue

- There should be awareness creation mechanism to increase participants in peer teaching program

- To create competent environment the club should be organized in different college that should have different objective beside peer teaching program

- This program should be integrated with instructors and academic advisors to use peer teaching as a very good strategy to help students in increasing their achievement. 


\section{REFERENCE}

1. Johnson, D. W., Johnson, R. T., \& Smith, K. A. (2014) Cooperative Learning: Improving University Instruction by Basing Practice on Validated Theory. Journal on Excellence in University Teaching, 25, 1-26.

2. Vygotsky, L. (1978). Mind in society. Cambridge, MA: M.I.T. Press.

3. Steinberg, L., Dornbusch, S. M., \& Brown, B. B. (1992). Ethnic differences in adolescent achievement: An ecological perspective. American Psychologist, 47:723-729.

4. Wentzel, K. R. (1999). Social-motivational processes and interpersonal relationships: Implications for understanding motivation at school. Journal of Educational Psychology, 91:7697.

5. Fuchs, D., Fuchs, L. S., Mathes, P. G., \& Martinez, E. A. (2002). Preliminary evidence on the social standing of students with learning disabilities in PALS and No-PALS classrooms. Learning Disabilities Research \& Practice, 17(4):205-215.

6. Rohrbeck, C. A., Ginsburg-Block, M. D., Fantuzzo, J. W., \& Miller, T. R. (2003). Peerassisted learning interventions with elementary school students: A meta-analytic review. Journal of educational Psychology, 95(2), 240-257.

7. Miller, S. R., \& Miller P. F. (1995). Cross-age peer tutoring. A strategy for promoting selfdetermination in students with severe emotional disabilities/behavior disorders. Preventing School Failure, 39(4):32-38.

8. Atieh, N. (1999). Educational Psychology (3rd ed.). Cairo: Anglo Egyptian Library.
9. Darwaza, A. (1997). Evaluating Questions and School's Evaluation (3rd ed.). Nablus: Al Farabi Library.

10. Saif, K. H. (2004). The Effect of Peer Teaching in Improving Mathematics Skills and Attitudes towards Mathematics of the Elementary Students in Kuwait. Educational Journal, 18.

11. Vasay, E. (2010). The Effect of Peer Teaching in the Performance of Students in Mathematics. EInternational Scientific Research Journal, 2:161.

12. Lord, T. (2001). 101 reasons for using cooperative learning in biology teaching. The American Biology Teacher, 63(1):30-38.

13. Al Deeb, M. (2006). Modern Strategies in Cooperative Learning (1st ed.). Cairo: Books World.

14. Hulya, H. (2004). The Effect of Peer Instruction on High School Students' Achievement and Attitudes towards Physics (Doctoral nunPublished degree). Ankara: Middle East Technical University.

15. John, W. C. (2012). Educational Research: Planning, Conducting, and Evaluatin Quantitative and Qualitative Research (Boston: Pearson), 309.

16. Abu Shaban, N. (2010). The Effect of Using the Peer Teaching Strategy for Developing the Critical Thinking Skills of Eleventh Students Grade in the Human Science Department in Gaza(Master nunPublished Degree). Gaza: Islamic University.

17. Ehly, S. W., \& Larsen, S. C. (1980). Peer Tutoring for Individualized Instruction. Boston: Allyn and Bacon, Inc.

18. Abdelkarim, R. E., \& Abuiyada, R. (2016). The Effect of Peer Teaching on Mathematics Academic Achievement of the Undergraduate Students in Oman. International Education Studies, 9(5), 124-132. 